Journal of Physical Science, Vol. 32(1), 91-108, 2021

\title{
Effective Removal of Reactive Brown 10 from Aqueous Solution by Using Chitosan Beads: Batch and Experimental Design Studies
}

\author{
Wan-Yean Chung ${ }^{1}$ and Siew-Teng Ong ${ }^{1,2^{*}}$ \\ ${ }^{1}$ Faculty of Science, Universiti Tunku Abdul Rahman, Jalan Universiti, \\ Bandar Barat, 31900 Kampar, Perak, Malaysia \\ ${ }^{2}$ Centre for Biodiversity Research, Universiti Tunku Abdul Rahman, Jalan Universiti, \\ Bandar Barat, 31900 Kampar, Perak, Malaysia
}

Corresponding author: ongst@utar.edu.my,ongst_utar@yahoo.com

Published online: 25 April 2021

To cite this article: Chung, W-Y. \& Ong, S-T. (2021). Effective removal of Reactive Brown 10 from aqueous solution by using chitosan beads: Batch and experimental design studies. J. Phys. Sci., 32(1), 91-108. https://doi.org/10.21315/jps2021.32.1.7

To link to this article: https://doi.org/10.21315/jps2021.32.1.7

\begin{abstract}
Application of chitosan bead as a low-cost adsorbent for removing Reactive Brown 10 (RB 10) from aqueous solution was investigated. The presence of $-\mathrm{NH}_{2}$ and $-\mathrm{OH}$ functional groups on chitosan beads were evident from the Fourier transform infrared (FTIR) spectrum. The changes on the surface morphology of the chitosan beads before and after sorption were analysed. Dye sorption was found higher with a longer contact time, lower dye concentration and greater adsorbent dosage. The optimum $\mathrm{pH}$ and adsorbent dosage for the adsorption of RB10 were $\mathrm{pH} \mathrm{4-6}$ and $0.04 \mathrm{~g}$, respectively. Both Langmuir and Brunauer, Emmett and Teller (BET) isotherm were determined as the appropriate model to describe the behaviour of the adsorption process. The maximum adsorption capacity was about $22 \mathrm{mg} \mathrm{g}^{-1}$. The significant variables in affecting the RB 10 uptake was identified using the Plackett-Burman (PB) program.
\end{abstract}

Keywords: Reactive Brown 10, chitosan, adsorption, isotherm study, Plackett-Burman

\section{INTRODUCTION}

The presence of dyes, even in trace quantities, is very undesirable in an aqueous environment because its high-colouring power gives rise to aesthetic damage. Generally, the volume of discharged wastewater from each textile operation step is around $401 \mathrm{~kg}^{-1}$ to $651 \mathrm{~kg}^{-1}$ of the product, which is considered a high rate. ${ }^{1}$ The high stability of dyes is due to their complex aromatic structures and synthetic 
origin, which attributes to fading and biodegrading resistance. However, the toxicity effect and environmental issues related to dyes are of great concern. ${ }^{2-4}$

Azo dyes are known to be the largest constituent of a water pollutant, and it can be potentially carcinogenic. ${ }^{5}$ The toxic amines will be released into the effluent when the azo linkages undergo reductive cleavage. One of the most commonly used types of dyes for dyeing cotton is the reactive dye. Due to the dye's widespread usage, the reactive dye removal from the environment is a noteworthy treatment process. Besides, some of the dyes or their intermediates are known to be toxic, mutagenic and carcinogenic. ${ }^{6,7}$ Reactive Brown 10 (RB 10) is an azo dye that contains a dichlorotriazine ring in its chemical structure. RB 10 was selected as the adsorbate in this study because it has been widely used in protein purification in dye-ligand affinity system. ${ }^{8-11}$

The conventional methods of colour removal from industrial effluent include chemical, biological and physical methods. Some of the physico-chemical water treatment methods like flocculation, precipitation, membrane filtration, coagulation, ion-exchange and adsorption techniques are extensively used to remove metal ions and other pollutants. ${ }^{12,13}$ Although activated carbon is a versatile and high sorption capacity adsorbent, the high production cost inhibits its application as an adsorbent in industrial scale.

Therefore, there is a need to search for an easily produced and efficient adsorbent for dye removal. In our continued effort to use low-cost materials for dye removal, chitosan was chosen as a potential adsorbent as it is an environment-friendly raw material. The adsorption efficiency of chitosan and its derivative have attracted much attention, and several reports also highlighted the potential usage of chitosan in removing different types of pollutant. ${ }^{14-17}$ However, in flakes form, the inconsistency in the particle size might affect the adsorption process efficiency. Also, the extra energy or equipment needed for the post-filtration process will add to the cost of wastewater treatment.

Therefore, in this study, chitosan would be modified into beads form to produce an adsorbent more consistent in sizes and overcome problems associated with the separation of fine particles mentioned earlier. Apart from studying the effect from various operational parameters, the investigation was extended to include experimental design to identify the significant variables that affect the dye uptake. 


\section{EXPERIMENTAL}

\subsection{Adsorbent}

Chitosan solution was prepared by dissolving three grams of chitosan flakes (degree of deacetylation $67.29 \%$, purchased from Sigma-Aldrich) into 1\% acetic acid solution. The chitosan solution was dropped into a $0.3 \mathrm{M} \mathrm{NaOH}$ solution using a syringe with continuous stirring. All other chemicals used in this study were of analytical reagent grade. The chitosan beads were rinsed with distilled water until they were completely neutralised and dried in an oven at $30^{\circ} \mathrm{C}$ overnight. The spherical chitosan beads produced had the diameter size within the 1-3 mm range.

\subsection{Adsorbates}

RB 10 was purchased from Sigma-Aldrich and used as received without any further purification. It has a molecular formula of $\mathrm{C}_{20} \mathrm{H}_{12} \mathrm{Cl}_{2} \mathrm{CrN}_{6} \mathrm{O}_{6} \mathrm{~S}$ with the molecular weight $587.31 \mathrm{~g} \mathrm{~mol}^{-1}$. A $100 \mathrm{mg} \mathrm{l}^{-1}$ dye solution was prepared as a stock solution and diluted when necessary.

\subsection{Characterisation}

A Fourier transform infrared (FTIR) spectrophotometer (Perkin Elmer FTIR, Spectrum RX1) with $400-4000 \mathrm{~cm}^{-1}$ wavenumber range was used to analyse the functional groups of chitosan. Scanning electron microscope (SEM) operated at an emission current of $3.0 \mathrm{kV}$ with a working distance of $4.6 \mathrm{~mm}$ (JEOL FESEM JSM 6701F) was used to analyse the surface morphology of chitosan.

\subsection{Batch Study}

Batch experiments were carried out at room temperature $\left(25^{\circ} \mathrm{C} \pm 2^{\circ} \mathrm{C}\right)$ by agitating $0.10 \mathrm{~g}$ of chitosan beads with $25 \mathrm{ml}$ of $25 \mathrm{mg} \mathrm{l}^{-1}$ dye solution in a centrifuge tube on an orbital shaker at $150 \mathrm{rpm}$ for $6 \mathrm{~h}$ unless otherwise stated. All the experiments were performed in duplicates, and the average results were recorded. The dye concentrations of the supernatant and the wavelength for maximum adsorption, $\lambda_{\max }$ were determined using UV/Visible-1700 Pharmaspec SHIMADZU doublebeam spectrometer. The $\lambda_{\max }$ of RB 10 was found to be $526 \mathrm{~nm}$.

The percentage uptake of dye was calculated based on the following equation:

$\%$ uptake $=\frac{\text { Initial dye concentration }- \text { Final dye concentration }}{\text { Initial dye concentration }} \times 100 \%$ 
The effect of initial dye concentrations and contact time was investigated with the dye concentrations set at $25 \mathrm{mg} \mathrm{l}^{-1}, 75 \mathrm{mg} \mathrm{l}^{-1}$ and $125 \mathrm{mg} \mathrm{l}^{-1}$. At predetermined time intervals, the dye solution was withdrawn and analysed for its dye concentration. For the effect of $\mathrm{pH}, \mathrm{HCl}$ and $\mathrm{NaOH}$ solutions in different molarities were used to adjust the desired $\mathrm{pH}$ of the dye solution ( $\mathrm{pH} 2-12)$. The percentage uptake of RB 10 by using different amount of chitosan beads was studied by varying the amount of chitosan beads used from $0.02-0.10 \mathrm{~g}$.

\subsection{Sorption Isotherm}

The adsorption isotherms were studied by varying the dye concentrations from $25 \mathrm{mg} \mathrm{l}^{-1}$ to $125 \mathrm{mg} \mathrm{l}^{-1}$. The experiments were performed by treating each of the $25 \mathrm{ml}$ of dye solution with $0.10 \mathrm{~g}$ of chitosan beads for $6 \mathrm{~h}$.

\subsection{Statistical Analysis via Plackett-Burman Design}

Plackett-Burman design was used to evaluate the relative importance of various factors that affect the adsorption of RB 10. The experimental designs were generated by the Design Expert version 7.1.3.1.

\section{RESULTS AND DISCUSSION}

\subsection{Characterisation of the Adsorbent}

From the FTIR spectrum (Figure 1), a broad and intense O-H stretching peak in the region of $3600-3000 \mathrm{~cm}^{-1}$ indicates the presence of the hydroxyl group. The peak observed at $3432 \mathrm{~cm}^{-1}$ corresponds to the amine stretching, and this can be used to confirm the secondary amine group in chitosan structure. A peak appears at $2925 \mathrm{~cm}^{-1}$ which might be due to stretching vibration of the $\mathrm{C}-\mathrm{H}$ bond of methylene and methine groups. The peaks around $2300 \mathrm{~cm}^{-1}$ and at $1649 \mathrm{~cm}^{-1}$ are due to $\mathrm{O}-\mathrm{H}$ stretching of the carboxylic group and $\mathrm{C}=\mathrm{O}$ stretching, respectively. The peak observed at $1376 \mathrm{~cm}^{-1}$ is associated with the $\mathrm{C}-\mathrm{N}$ stretching. The peaks found at $1153 \mathrm{~cm}^{-1}$ and $1074 \mathrm{~cm}^{-1}$ are assigned to $\mathrm{C}-\mathrm{O}$ stretching. In addition, the peak at $610 \mathrm{~cm}^{-1}$ indicates the presence of $\mathrm{C}-\mathrm{OH}$ twist. 


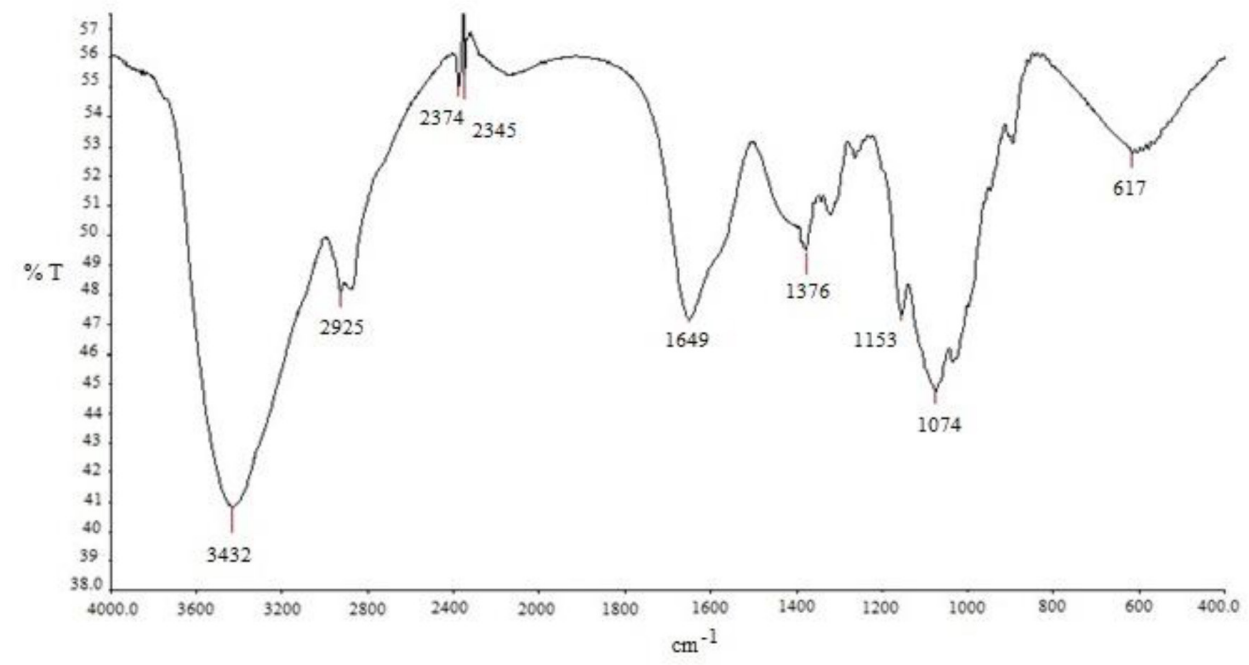

Figure 1: FTIR spectrum of chitosan beads.

The surface morphology of chitosan beads was studied using SEM. The results showed that there was not much difference in the surface morphology of the adsorbent before and after the adsorption process. This indicates that the adsorbent was capable of retaining its morphology even after the dye adsorption process. The surface of native chitosan beads was a typically wrinkled polymeric network since chitosan is a linear homopolymer of glucose and it has a similar morphology with cellulose. ${ }^{18}$ The chitosan beads were deduced as non-porous material based on the SEM results.

(a)

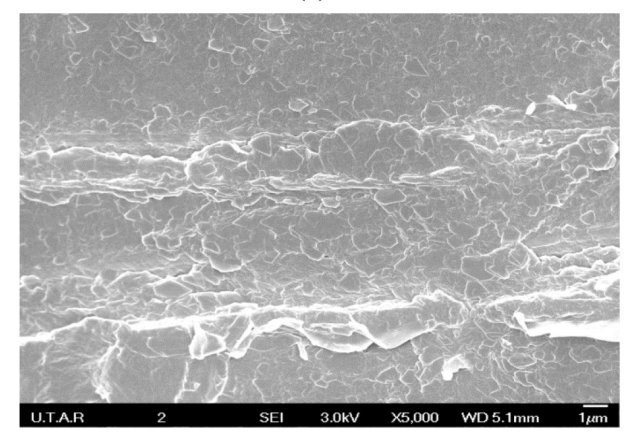

(b)

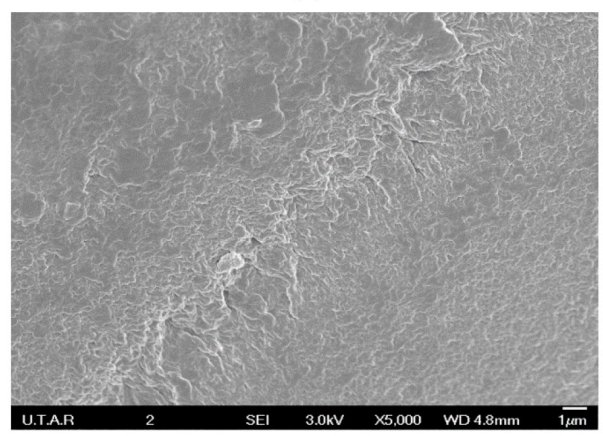

Figure 2: SEM micrograph of chitosan beads (a) before adsorption, and (b) after adsorption. 


\subsection{Adsorption}

\subsubsection{Effect of initial dye concentrations and contact time}

The dye adsorption was a fast process at the beginning, but thereafter, it took approximately $360 \mathrm{~min}$ to achieve equilibrium (Figure 3 ). This is most probably due to the occurrence of two or more steps in the adsorption process, and this adsorption trend was similar to the previously reported work. ${ }^{19}$ A large amount of vacant binding sites of chitosan beads at the initial stage of adsorption contributed to the rapid uptake process. Once the binding sites of chitosan beads become saturated, this turned into a limiting factor for dye uptake.

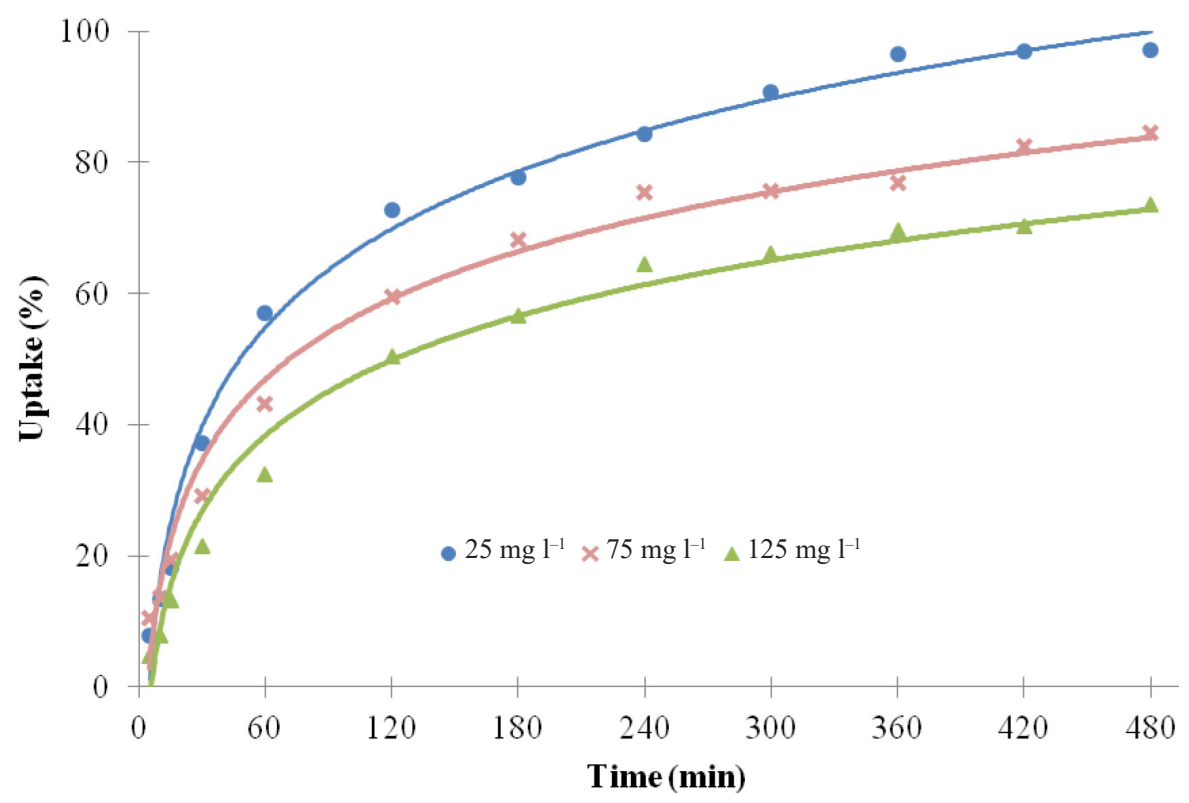

Figure 3: Effect of initial dye concentrations and contact time on percentage uptake of RB 10 by chitosan beads ( 0.10 g chitosan beads; $25 \mathrm{ml} ; \mathrm{pH}: 4.83,150 \mathrm{rpm})$.

The percentage uptake of RB 10 decreased with increasing initial dye concentration from $25 \mathrm{mg} \mathrm{l}^{-1}$ to $125 \mathrm{mg}^{-1}$. This observation was closely related to the fixed amount of sorbent dosage. At higher dye concentration, many dye molecules competed strongly for the limited sorption sites, and as a consequence, a large number of dye molecules were not being removed successfully. The adsorption trend for this effect was similar to the findings published by other researchers. ${ }^{20}$ 


\subsubsection{Effect of $\mathrm{pH}$}

The graph of percentage uptake against $\mathrm{pH}$ (Figure 4) agrees well with the results reported by other researchers. ${ }^{21-23}$ The maximum adsorption occurred at $\mathrm{pH} 4$, and the dye uptake was markedly decreased at $\mathrm{pH}$ greater than 7 . This is related to the isoelectric point for chitosan, which is determined as $\mathrm{pH}$ 6.9. There was only a slight difference compared with the isoelectric point reported by Luk et al., which was around $\mathrm{pH} 8 .{ }^{24}$

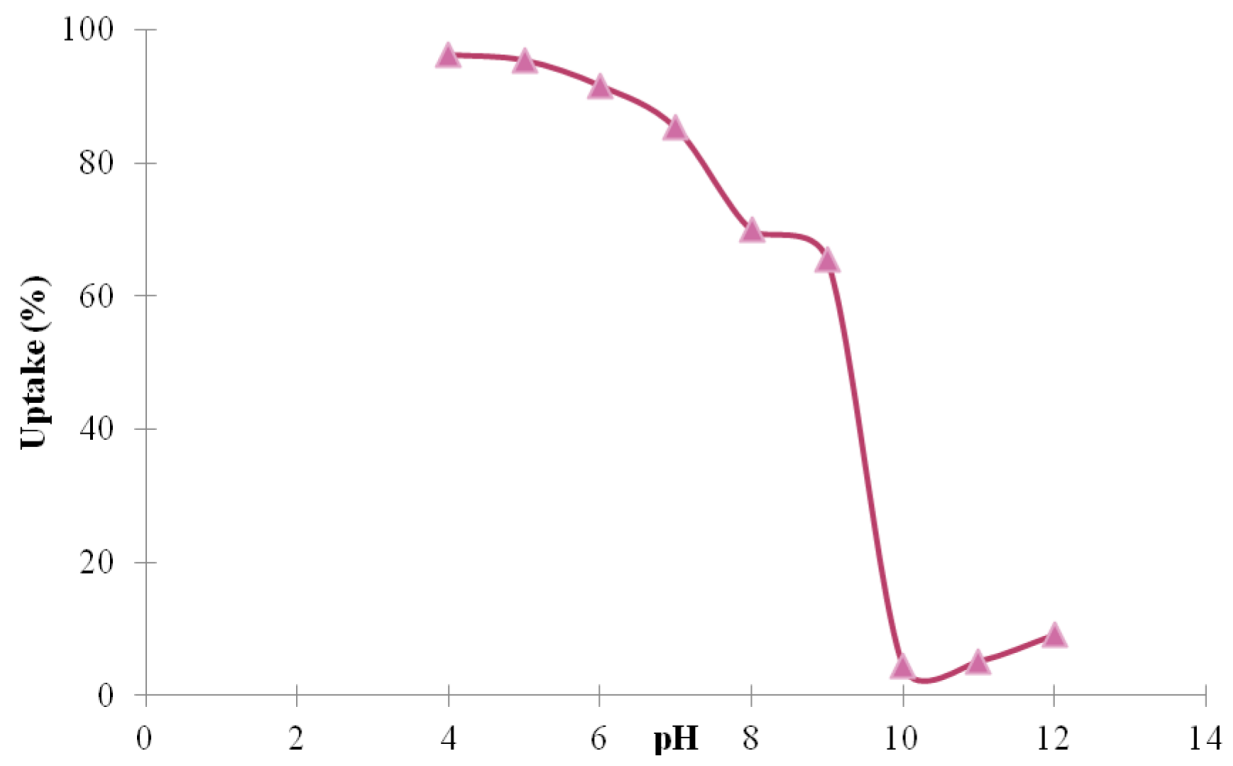

Figure 4: Effect $\mathrm{pH}$ on percentage uptake of RB 10 by chitosan beads $(0.10 \mathrm{~g}$ chitosan beads; $25 \mathrm{ml}$ of $25 \mathrm{mg} \mathrm{l}^{-1}$ of RB 10; $150 \mathrm{rpm}$ ).

However, as chitosan dissolved and formed hydrogel under extreme acidic condition, the effect of $\mathrm{pH}$ was not studied beyond $\mathrm{pH} 4$. In acidic condition, chitosan dissolved as polycation where its amine functional group was protonated. The protonation of the amine group was necessary for electrostatic interaction between adsorbent and dye molecules. Decreasing the $\mathrm{pH}$ value would increase the supply of hydrogen ion for protonation and enhance the attraction of negatively charged sulfonic group of RB 10 towards the cationic amines.

The $\mathrm{pK}_{\mathrm{a}}$ of amine group was reported to be $\mathrm{pH} 6.5$, so a decreasing trend of uptake was observed from $\mathrm{pH} 7$ to $10 .{ }^{25}$ From the current result, there was still some uptake of the dye in the range of $\mathrm{pH} 7$ to 12 . This might be due to other sorption interactions, such as van der Waals forces and hydrogen bonding occurring at 
the same time. Similar results were reported in the adsorption of Congo Red by chitosan hydro beads, where various interactions were proposed to be responsible for the dye uptake. ${ }^{26}$

The hydroxyl group of chitosan possibly dissociated in alkaline condition as follow:

$$
-\mathrm{CH}_{2} \mathrm{OH}+\mathrm{OH}^{-} \longleftrightarrow \mathrm{CH}_{2} \mathrm{O}^{-}+\mathrm{H}_{2} \mathrm{O}
$$

The resulting anion could substitute the chloride atom from the dye molecule, and this is similar to the dyeing process of reactive dyes onto fabrics. ${ }^{27}$

$$
-\mathrm{CH}^{2} \mathrm{O}^{-}+\mathrm{D}-\mathrm{C} 1 \rightarrow \mathrm{CH}_{2}-\mathrm{O}-\mathrm{D}+\mathrm{C1}^{-}
$$

\subsubsection{Sorption isotherm}

The sorption equilibrium data were analysed using Langmuir, Freundlich and Brunauer, Emmett and Teller (BET) models.

The linear form of Langmuir isotherm was represented as: ${ }^{28}$

$$
\frac{C_{e}}{q_{e}}=\frac{1}{q_{m} K_{L}}+\frac{C_{e}}{q_{m}}
$$

A linear graph of $C_{e} / q_{e}$ against $\mathrm{C}_{\mathrm{e}}$ was plotted (Figure 5). The maximum adsorption capacity $\left(q_{m}\right)$ of RB 10 and Langmuir constant $\left(K_{L}\right)$ were calculated as $22.52 \mathrm{mg} \mathrm{g}^{-1}$ and $1.21991 \mathrm{mg}^{-1}$, respectively. Apart from using naturally occurring materials or locally available waste materials, the resin can also serve as a potential adsorbent for RB 10 removal. By using magnetic resin, the maximum adsorption capacity was recorded as $162.4 \mathrm{mg} \mathrm{g}^{-1} .{ }^{29}$ In another work, the modified resin demonstrated a maximum adsorption capacity of $0.029 \mathrm{mmol} \mathrm{g}^{-1}$ for the same dye. ${ }^{30}$ 


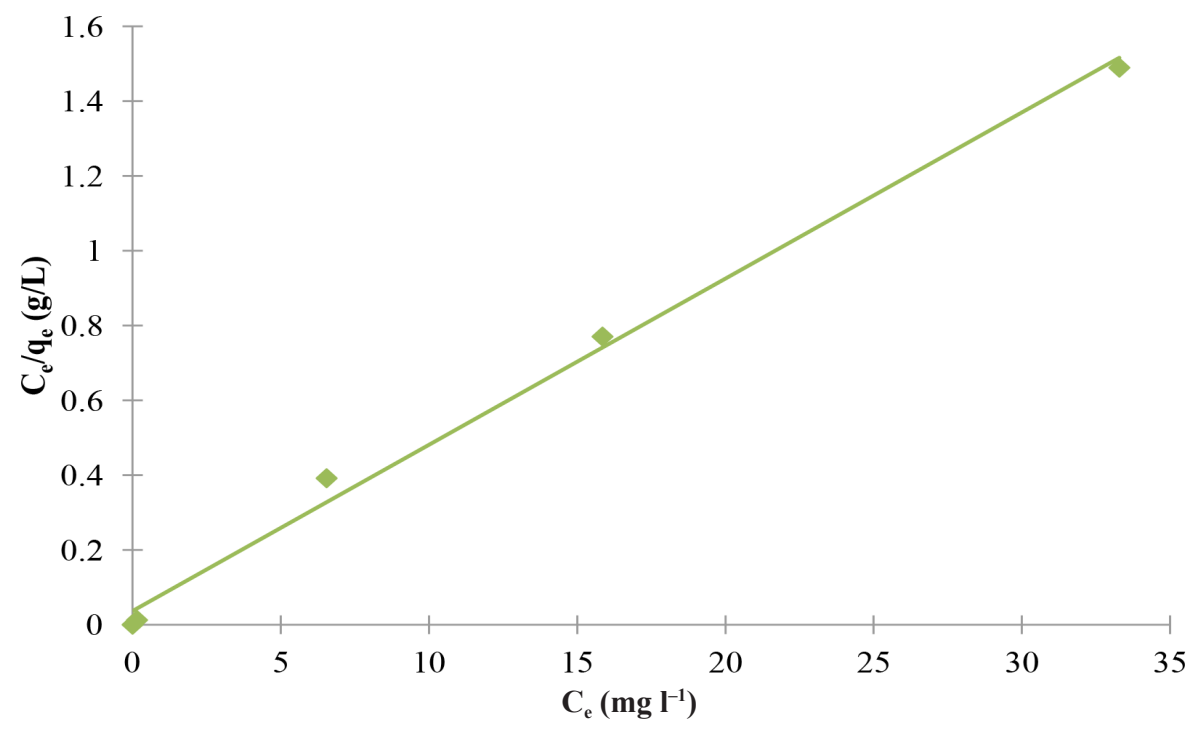

Figure 5: Langmuir isotherm of RB 10 by chitosan beads ( $0.10 \mathrm{~g}$ chitosan beads; $25 \mathrm{ml}$; $\mathrm{pH}: 4.83 ; 150 \mathrm{rpm})$.

The dimensionless equilibrium parameter, $\mathrm{R}_{\mathrm{L}}$, which indicates the important characteristic of Langmuir isotherm, can be calculated by using Equation 5:

$$
R_{L}=\frac{1}{1+K_{L} C_{O}}
$$

where $C_{o}=$ initial concentration of dye $\left(\mathrm{mg} \mathrm{l}^{-1}\right)$

The favourability of adsorption system could be predicted by the $R_{L}$ value (Table 1). The decreasing $R_{L}$ values obtained from the concentration of $25 \mathrm{mg} \mathrm{l}^{-1}$ to $125 \mathrm{mg} \mathrm{l}^{-1}$ (Table 2) indicated that the uptake behaviour of the system skewed towards the irreversible case. 
Table 1: Types of isotherm.

\begin{tabular}{lc}
\hline$R_{L}$ value & Type of isotherm \\
\hline$R_{L}>1$ & Unfavourable \\
$R_{L}=1$ & Linear \\
$0<R_{L}<1$ & Favourable \\
$R_{L}=0$ & Irreversible \\
\hline
\end{tabular}

Table 2: $\mathrm{R}_{\mathrm{L}}$ values for the $\mathrm{RB} 10$ dye concentration range studied.

\begin{tabular}{cc}
\hline Dye concentration $\left(\mathrm{mg}^{-1}\right)$ & $R_{L}$ \\
\hline 25 & 0.0330 \\
50 & 0.0166 \\
75 & 0.0110 \\
100 & 0.0083 \\
125 & 0.0066 \\
\hline
\end{tabular}

The Freundlich model ${ }^{31}$ does not predict surface saturation. It considers the existence of a multilayer structure. The linearised form of Freundlich equation is as follows:

$$
\log \mathrm{q}_{\mathrm{e}}=\log \mathrm{K}_{\mathrm{F}}+\frac{1}{\mathrm{n}} \log \mathrm{C}_{\mathrm{e}}
$$

The graph of $\log \mathrm{q}_{\mathrm{e}}$ against $\log \mathrm{C}_{\mathrm{e}}$ was shown in Figure 6. The $\mathrm{R}^{2}$, Freundlich constant $\left(\mathrm{K}_{\mathrm{F}}\right)$ and sorption intensity $(\mathrm{n})$ were $0.9616,14.69 \mathrm{mg} \mathrm{g}^{-1}$ and 8.9928, respectively. The $n$ value implies the favourability of the sorption system where $1<\mathrm{n}<10$ represents good sorption characteristic. ${ }^{32}$ 


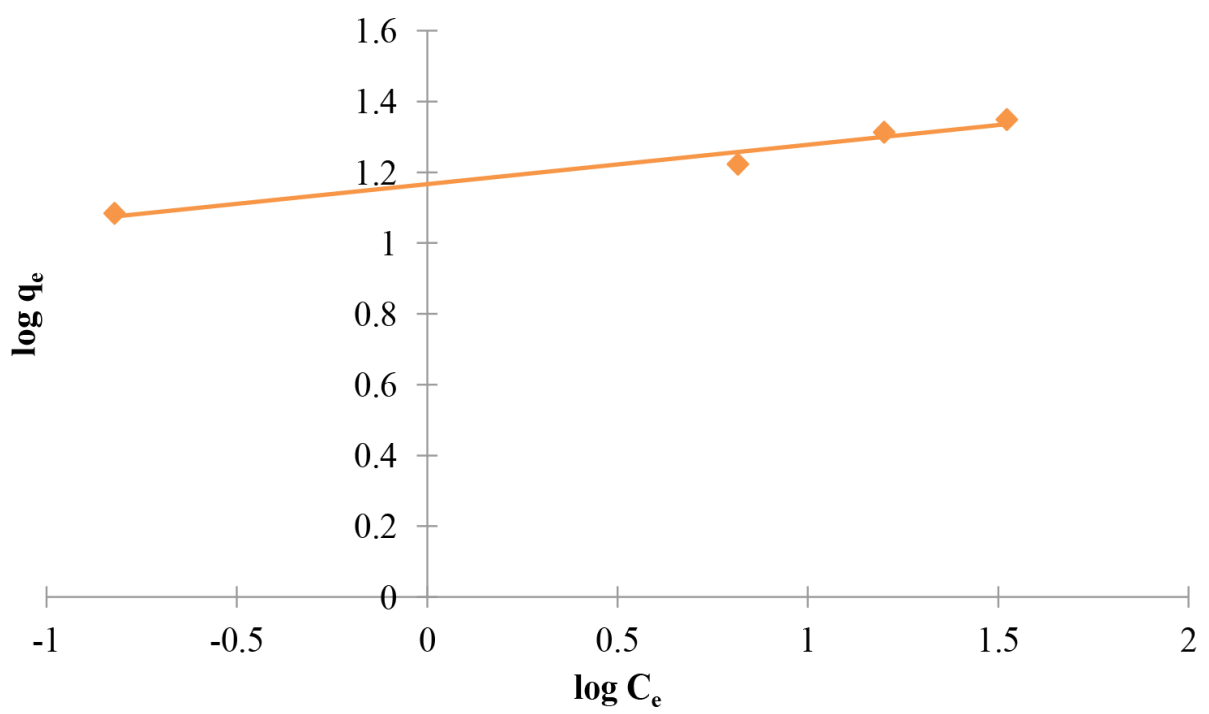

Figure 6: Freundlich isotherm of RB 10 by chitosan beads ( $0.10 \mathrm{~g}$ chitosan beads; $25 \mathrm{ml}$; $\mathrm{pH}: 4.83 ; 150 \mathrm{rpm})$.

The BET isotherm model is an extension of Langmuir theory, and the linear form of the BET model is represented as: $:^{33}$

$$
\frac{C_{e}}{\left(C_{s}-C_{e}\right) q_{e}}=\frac{1}{K_{B} x_{m}}+\left(\frac{K_{B}-1}{K_{B} x_{m}}\right)\left(\frac{C_{e}}{C_{s}}\right)
$$

where $x_{m}=$ amount of solute in forming a complete monolayer $\left(\mathrm{mg} \mathrm{g}^{-1}\right)$ and $C_{S}=$ saturation concentration of solute $\left(\mathrm{mg}^{-1}\right)$.

The BET plot was depicted in Figure 7, with $\mathrm{R}^{2}$ of 0.9950 . The amount of solute in forming a complete monolayer, $x_{m}$ and BET dimensionless constant, $K_{B}$ were determined as $22.42 \mathrm{mg} \mathrm{g}^{-1}$ and 44601, respectively.

The equilibrium data fitted well into both Langmuir and BET isotherm with high $\mathrm{R}^{2}$ values (Table 3 ). In a nutshell, uptake behaviour of RB 10 by chitosan beads followed multilayer adsorption pattern with the homogenous surface energy system. Chitosan is considered a natural material with an irregular and mixedsurface morphology, and this explains why its sorption behaviour showed good conformity with different isotherm models. The applicability of different isotherm models in the adsorption process by various adsorbents has been reported previously. ${ }^{19,34,35}$ 


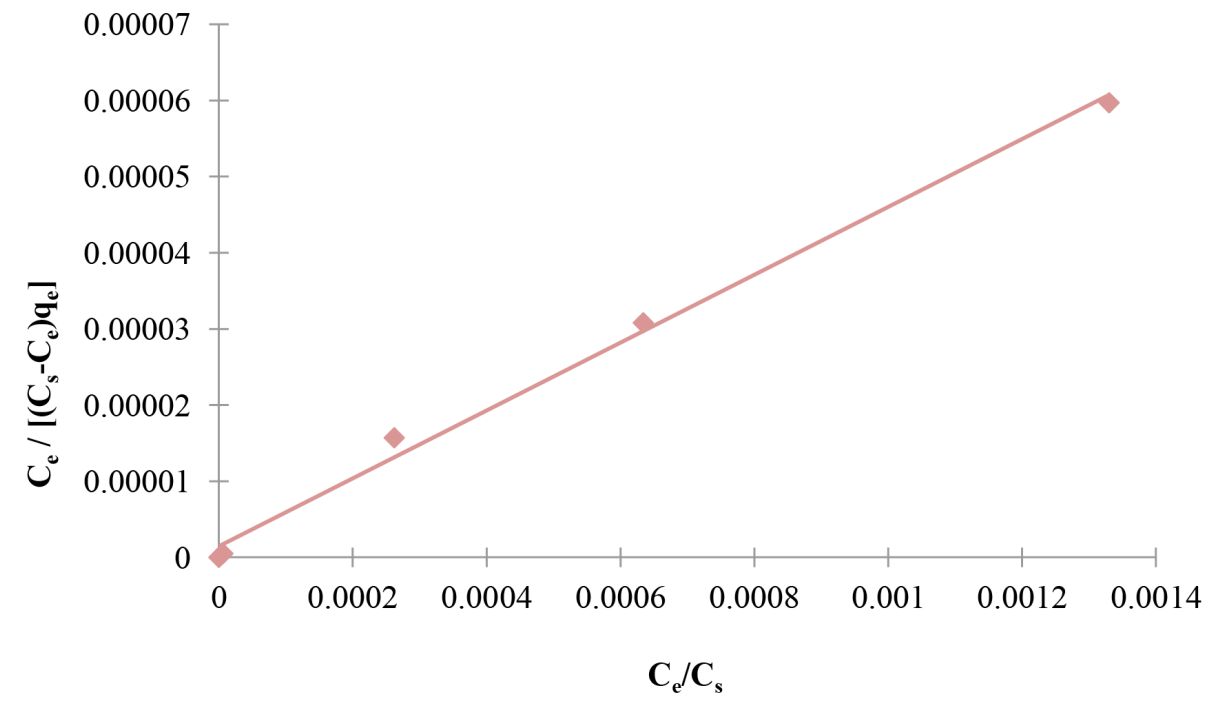

Figure 7: BET isotherm of RB 10 by chitosan beads $(0.10 \mathrm{~g}$ chitosan beads; $25 \mathrm{ml}$; pH $4.83 ; 150 \mathrm{rpm})$.

Table 3: Langmuir, Freundlich and BET isotherm parameters.

\begin{tabular}{lcc}
\hline Langmuir & $\mathrm{K}_{\mathrm{L}}\left(\mathrm{l} \mathrm{mg}^{-1}\right)$ & 1.2199 \\
& $\mathrm{q}_{\mathrm{m}}\left(\mathrm{mg} \mathrm{g}^{-1}\right)$ & 22.52 \\
Freundlich & $\mathrm{R}^{2}$ & 0.9948 \\
& $\mathrm{~K}_{\mathrm{F}}\left(\mathrm{mg} \mathrm{g}^{-1}\right)$ & 14.69 \\
$\mathrm{n}$ & 8.9928 \\
BET & $\mathrm{R}^{2}$ & 0.9616 \\
& $\mathrm{~K}_{\mathrm{B}}$ & 44601 \\
& $\mathrm{x}_{\mathrm{m}}\left(\mathrm{mg} \mathrm{g}^{-1}\right)$ & 22.42 \\
$\mathrm{R}^{2}$ & 0.9950 \\
\hline
\end{tabular}

\subsubsection{Effect of adsorbent dosage}

With the increasing adsorbent dosage from $0.02 \mathrm{~g}$ to $0.1 \mathrm{~g}$, the number of vacant active sites of chitosan beads provided for adsorption also increased, leading to a higher percentage uptake. Similar phenomena have been reported in removing Methylene Blue by activated carbon derived from rubber seed shell and the decolourisation of palm oil mill effluent (POME) by treated coal bottom 
ash. ${ }^{36,37}$ Saturation occurred at $0.04 \mathrm{~g}$ dosage with an initial dye concentration of $25 \mathrm{mg} \mathrm{l}^{-1}$, and this is the point where further increase in dosage had minimal effect on the decolourisation process.

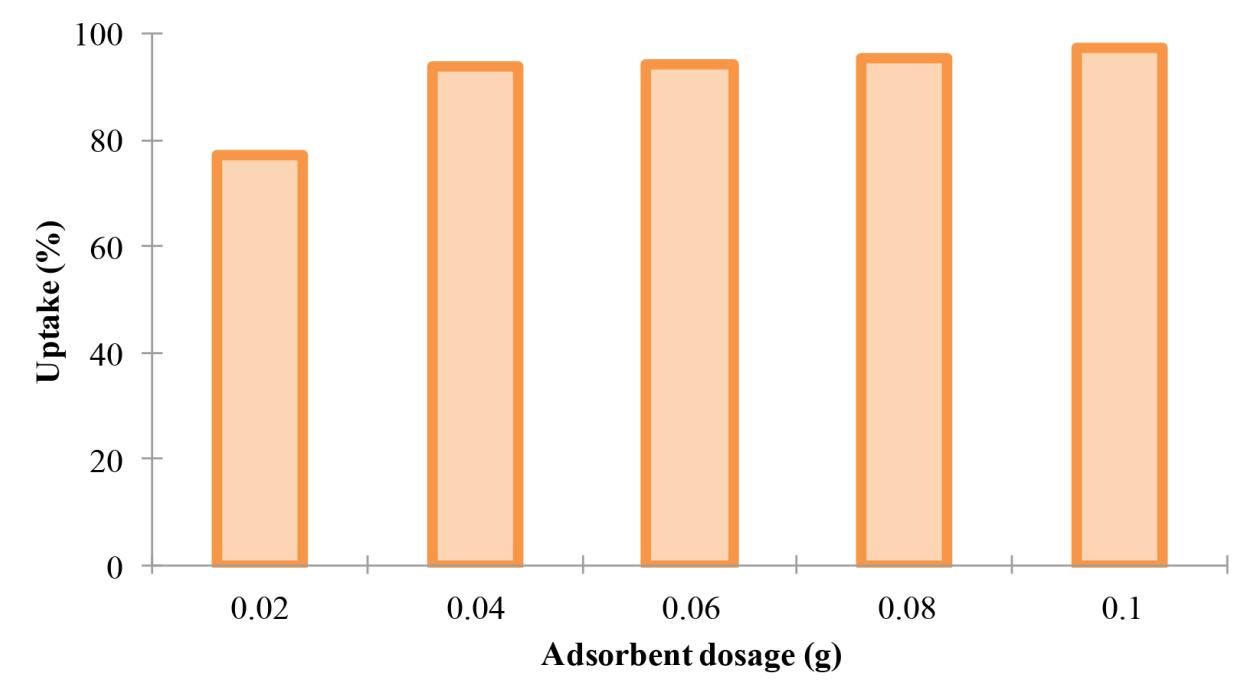

Figure 8: Effect of adsorbent dosage on the percentage uptake of RB 10 by chitosan beads ( $25 \mathrm{ml}$ of $25 \mathrm{mg} \mathrm{l}^{-1}$ of RB 10; $\mathrm{pH} \mathrm{4.83;150} \mathrm{rpm).}$

\subsection{Statistical Analysis - Plackett-Burman}

The experimental conditions generated by Plackett-Burman program, which included parameters of $\mathrm{pH}$, adsorbent dosage and initial dye concentrations, were tabulated and shown in Table 4. The minimum and maximum values were based on the experimental condition adopted under batch study. The experimental uptake apparently did not deviate much from the predicted uptake, and the differences were within a narrow range of $0.46 \%-8.5 \%$, which is most likely due to the nonnegligible effect of insignificant variables in the design., ${ }^{7,19,38}$ It thus appeared that this program can be used in studying different influential variables in affecting the dye uptake adsorption process. Some of the previously reported works have also demonstrated the usefulness of using this program in identifying significant factors for dye uptake. $7,38,39$ 
Table 4: Plackett-Burman generated experimental conditions and the comparison uptake of RB 10.

\begin{tabular}{ccccccc}
\hline $\begin{array}{c}\text { Experimental } \\
\text { run }\end{array}$ & $\begin{array}{c}\text { Adsorbent } \\
\text { dosage }(\mathrm{g})\end{array}$ & $\mathrm{pH}$ & $\begin{array}{c}\text { Initial dye } \\
\text { concentration } \\
\left(\mathrm{mg} \mathrm{l}^{-1}\right)\end{array}$ & $\begin{array}{c}\text { Experimental } \\
\text { uptake }(\%)\end{array}$ & $\begin{array}{c}\text { Predicted } \\
\text { uptake } \\
(\%)\end{array}$ & $\begin{array}{c}\text { Differences } \\
(\%)\end{array}$ \\
\hline 1 & 0.10 & 12 & 25 & 9.07 & 17.55 & 8.49 \\
2 & 0.02 & 12 & 125 & 0.63 & 0.00079 & 0.63 \\
3 & 0.02 & 12 & 25 & 0.55 & 0.09 & 0.46 \\
4 & 0.02 & 4 & 25 & 67.15 & 65.54 & 1.62 \\
5 & 0.10 & 4 & 125 & 77.13 & 73.01 & 4.12 \\
6 & 0.10 & 12 & 125 & 3.01 & 7.56 & 4.55 \\
\hline
\end{tabular}

\subsection{ANOVA Analysis}

From the result shown in Table 5, the model was identified as a significant model with the Prob $>$ F value of $<0.0001$. The model was termed as significant if the value of Prob $>$ F was less than 0.05. From the result, it can be seen that both $\mathrm{pH}$ and adsorbent dosage appeared to be the significant factors during the decolourisation process by chitosan beads. This finding agreed well with most of the reported works in conventional batch studies. ${ }^{40,41}$

The ability of chitosan beads to adsorb an adsorbate was usually attributed by the surface charge of the adsorbent and also the degree of dissociation of the adsorbate. It is well known that both properties are greatly affected by $\mathrm{pH}$. The effect of chitosan bead dosage in dye uptake was caused by the availability of active sites of chitosan in aqueous solution. The uptake of dye increase as the amount of chitosan beads increase because more active sites of chitosan beads were available for taking up the dye molecules.

Table 5: ANOVA analysis for the remediation of RB 10 from aqueous solution.

\begin{tabular}{lcccccc}
\hline Source & $\begin{array}{c}\text { Degree of } \\
\text { freedom }\end{array}$ & $\begin{array}{c}\text { Sum } \\
\text { of squares }\end{array}$ & $\begin{array}{c}\text { Mean } \\
\text { squares }\end{array}$ & F-value & Prob $>$ F & Description \\
\hline Model & 3 & 14063.72 & 4687.91 & 30.87 & $<0.0001$ & Significant \\
$\mathrm{pH}$ & 1 & 12849.14 & 12849.14 & 84.60 & $<0.0001$ & Significant \\
$\begin{array}{l}\text { Adsorbent } \\
\text { dosage }\end{array}$ & 1 & 915.08 & 915.08 & 6.02 & 0.0397 & Significant \\
$\begin{array}{l}\text { Initial } \\
\text { concentration }\end{array}$ & 1 & 299.50 & 299.50 & 1.97 & 0.1979 & Not significant \\
\hline
\end{tabular}




\section{CONCLUSION}

This study demonstrated the potential of chitosan beads as a promising low-cost adsorbent for the remediation of RB 10 from aqueous solution. Further study can include the investigation under continuous flow condition which would be applicable to commercial systems. The findings revealed that the uptake efficiency was highly $\mathrm{pH}$-dependent, and the optimum $\mathrm{pH}$ was reported in the range of $\mathrm{pH}$ 4-6. The optimum dosage needed for RB 10 removal was found to be $0.04 \mathrm{~g}$. The important functional groups that are responsible in RB 10 uptake were $\mathrm{NH}_{2}$ and $-\mathrm{OH}$. SEM micrographs revealed that the investigated adsorbent is a non-porous type material. The equilibrium data obtained conformed well to Langmuir and $\mathrm{BET}$ isotherm with high $\mathrm{R}^{2}$. From the Plackett-Burman design, $\mathrm{pH}$ and adsorbent dosage were identified as non-negligible factors in determining the percentage uptake of RB 10.

\section{ACKNOWLEDGEMENTS}

The authors are thankful for the financial support and research facilities provided Universiti Tunku Abdul Rahman, Malaysia.

\section{REFERENCES}

1. Mezohegyi, G. et al. (2012). Towards advanced aqueous dye removal processes: A short review on the versatile role of activated carbon. J. Environ. Manage., 102, 148-164. https://doi.org/10.1016/j.jenvman.2012.02.021

2. Alaqarbeh, M., Shammout, M. \& Awwad, A. (2020). Nano platelets kaolinite for the adsorption of toxic metal ions in the environment. Chem. Int., 6, 49-55. https:// doi.org/10.5281/zenodo.3361011

3. Minas, F., Chandravanshi, B. S. \& Leta, S. (2017). Chemical precipitation method for chromium removal and its recovery from tannery wastewater in Ethiopia. Chem. Int., 3, 392-405.

4. Djehaf, K. et al. (2017). Textile wastewater in Tlemcen (Western Algeria): Impact, treatment by combined process. Chem. Int., 3, 414-419.

5. Chung, K. T. (2016). Azo dyes and human health: A review. J. Environ. Sci. Health C Environ. Carcinog. Ecotoxicol. Rev., 34, 233-261. https://doi.org/10.1080/105 90501.2016.1236602

6. Lellis, B. et al. (2019). Effects of textile dyes on health and the environment and bioremediation potential of living organisms: Review article. Biotechnol. Res. Inno., 3, 275-290. https://doi.org/10.1016/j.biori.2019.09.001

7. Lee, S. L., Liew, S. W. \& Ong, S. T. (2016). Experimental design approach for methylene Blue removal in aqueous environment by nitrilotriacetic modified banana pith.Acta Chim. Slov., 63, 144-153.https://doi.org/10.17344/acsi.2015.2068 
8. Denizli, A. \& Piskin, E. (2001). Dye-ligand affinity systems. J. Biochem. Biophys. Met., 49, 391-416. https://doi.org/10.1016/S0165-022X(01)00209-3

9. Chen, T. X. et al. (2009). Comparison: Adsorption of papain using immobilized dye ligands on affinity membranes. Coll. Surf. B, 72, 25-31. https://doi.org/10.1016/j. colsurfb.2009.03.012

10. Yilmaz, F. et al. (2007). Reactive Brown 10-attached polyamide hollow fiber for reversible amyloglucosidase immobilization. Hacet. J. Biol. Chem., 35, 149-155.

11. Wang, C. et al. (2013). Purification of phosphinothricin acetyltransferase using Reactive brown 10 affinity in a single chromatography step. Protein Expression Purif., 90, 129-134. https://doi.org/10.1016/j.pep.2013.05.011

12. Alkherraz, A. M., Ali, A. K. \& Elsherif, K. M. (2020). Removal of Pb (II), Zn (II), $\mathrm{Cu}$ (II) and $\mathrm{Cd}$ (II) from aqueous solutions by adsorption onto olive branches activated carbon: Equilibrium and thermodynamic studies. Chem. Int., 6, 11-20, https://doi.org/10.5281/zenodo.2579465

13. Jamal, M. A., Muneer, M. \& Iqbal, M. (2015). Photo-degradation of monoazo dye blue 13 using advanced oxidation process. Chem. Int., 1, 12-16.

14. Noreen, S. et al. (2020). Chitosan, starch, polyaniline and polypyrrole biocomposite with sugarcane bagasse for the efficient removal of Acid Black dye. Int. J. Bio. Macromol., 147, 439-452, https://doi.org/10.1016/j.ijbiomac.2019.12.257

15. Kausar, A. et al. (2019). Preparation and characterization of chitosan/clay composite for direct Rose FRN dye removal from aqueous media: Comparison of linear and non-linear regression methods, J. Mater. Res. Technol., 8, 1161-1174. https://doi.org/10.1016/j.jmrt.2018.07.020

16. Bilal, M. et al. (2016). Chitosan beads immobilized manganese peroxidase catalytic potential for detoxification and decolorization of textile effluent, Int. J. Bio. Macromol., 89, 181-189. https://doi.org/10.1016/j.ijbiomac.2016.04.075

17. Tahir, N. et al. (2017). Biopolymers composites with peanut hull waste biomass and application for Crystal Violet adsorption. Int. J. Bio. Macromol., 94, 210-220. https://doi.org/10.1016/j.ijbiomac.2016.10.013

18. Ilhan, U. (2006). Kinetics of the adsorption of reactive dyes by chitosan. Dyes Pigm., 70, 76-83. https://doi.org/10.1016/j.dyepig.2005.04.016

19. Ong, S. T. \& Seou, C. K. (2015). Removal of reactive black 5 from aqueous solution using chitosan beads: Optimization by Plackett-Burmann design and response surface analysis. Desalin. Water Treat. J., 52, 7673-7684. https://doi.org /10.1080/19443994.2013.830684

20. Sadeghi-Kiakhani, M., Arami, M. \& Gharanjig, K. (2013). Dye removal from colored-textile wastewater using chitosan-PPI dendrimer hybrid as a biopolymer: Optimization, kinetic and isotherm studies. J. Appl. Polym. Sci., 127, 2607-2619. https://doi.org/10.1002/app.37615

21. Knorr, D. (1983). Dye binding properties of chitin and chitosan. J. Food Sci., 48, 36-37. https://doi.org/10.1111/j.1365-2621.1983.tb14783.x

22. Kyzas, G. Z. \& Lazaridis, N. K. (2009). Reactive and basic dyes removal by sorption onto chitosan derivatives. J. Coll. Interf. Sci., 331, 32-39. https://doi. org/10.1016/j.jcis.2008.11.003 
23. Bayramoglu, G. \& Arica, M. Y. (2013). Removal of reactive dyes from wastewater by acrylate polymer beads bearing amino groups: Isotherm and kinetic studies. Colour. Technol., 129, 114-124. https://doi.org/10.1111/cote.12012

24. Luk, C. J. et al. (2014). A comprehensive study on adsorption behaviour of direct, reactive and acid dyes on crosslinked and non-crosslinked chitosan beads. J. Fib. Bioeng. Info., 7, 35-52. https://doi.org/10.3993/jfbi03201404

25. Gibbs, G., Tobin, J. M. \& Guibal, E. (2003). Sorption of acid green 25 on chitosan: Influence of experimental parameters on uptake kinetics and sorption isotherms. $J$. Appl. Polym. Sci., 90, 1073-1080. https://doi.org/10.1002/app.12761

26. Chatterjee, S. et al. (2007). Adsorptive removal of congo red, a carcinogenic textile dye by chitosan hydrobeads: Binding mechanism, equilibrium and kinetics. Coll. Surf. A Physicochem. Eng. Asp., 299, 146-152. https://doi.org/10.1016/j. colsurfa.2006.11.036

27. Sakkayawong, N., Thiravetyan, P. \& Nakbanpote, W. (2005). Adsorption mechanism of synthetic reactive dye wastewater by chitosan. J. Coll. Interf. Sci., 286, 36-42. https://doi.org/10.1016/j.jcis.2005.01.020

28. Langmuir, I. (1918). The adsorption of gases on plane surfaces of glass, mica and platinum. J. Am. Chem. Soc., 40, 1361-1368. https://doi.org/10.1021/ja02242a004

29. Bayramoglu, G. et al. (2017). Removal of metal complexed azo dyes from aqueous solution using tris(2-aminoethyl)amine ligand modified magnetic p(GMAEGDMA) cationic resin: Adsorption, isotherm and kinetic studies. Chem. Eng. Res. Des., 124, 85-97. https://doi.org/10.1016/j.cherd.2017.06.005

30. Bayramoglu, G. \& Arica, M.Y. (2013). Removal of reactive dyes from wastewater by acrylate polymer beads bearing amino groups: Isotherm and kinetic studies. Color. Technol., 129, 114-124. https://doi.org/10.1111/cote.12012

31. Freundlich, H. (1906). Adsorption in solution. J. Phys. Chem., 57, 385-471.

32. Annadurai, G., Ling, L. Y. \& Lee, J. F. (2007). Adsorption of reactive dye from an aqueous solution by chitosan: Isotherm, kinetic and thermodynamic analysis. $J$. Hazard. Mater., 152, 337-346. https://doi.org/10.1016/j.jhazmat.2007.07.002

33. Brunauer, S., Emmett, P. H. \& Teller, E. (1938). Adsorption of gases in multimolecular layers. J. Am. Chem. Soc., 60, 309-319. https://doi.org/10.1021/ ja01269a023

34. Tay, C. I. \& Ong, S. T. (2019). Guava leaves as adsorbent for the removal of emerging pollutant: Ciprofloxacin from aqueous solution. J. Phys. Sci., 30, 137156. https://doi.org/10.21315/jps2019.30.2.8

35. Ooi, S. L. \& Ong, S. T. (2019). Remediation of lead (II) and malachite green from aqueous solution using palm oil fruit fiber. Stud. UBB Chem., 4, 55-70.

36. Azani, N. F. S. et al. (2019). Characterisation and kinetic studies on activated carbon derived from rubber seed shell for the removal of methylene blue in aqueous solutions. J. Phys. Sci., 30, 1-20. https://doi.org/10.21315/jps2019.30.2.1

37. Saleh, S., Wan, Ab. K. G. W. A. \& Soh, K. L. (2019). Treated coal bottom ash for palm oil mill effluent (POME) decolourisation. J. Phys. Sci., 30, 101-116. https:// doi.org/10.21315/jps2019.30.3.7 
38. Gan, H. Y., Leow, L. E. \& Ong, S. T. (2017). Utilization of corn cob and $\mathrm{TiO}_{2}$ photocatalyst thin films for dyes removal. Acta Chim. Slov., 64, 144-158. https:// doi.org/10.17344/acsi.2016.2983

39. Ong, S. T. et al. (2015). Application of conventional and statistical experimental methodology to optimize malachite green dye removal from aqueous solutions. Desalin. Water Treat. J., 55, 1359-1371. https://doi.org/10.1080/19443994.2014 .925830

40. Bhatnagar, A. \& Sillanpaa, M. (2009). Applications of chitin- and chitosanderivatives for the detoxification of water and wastewater: A short review. Adv. Coll. Interf. Sci., 152, 26-38. https://doi.org/10.1016/j.cis.2009.09.003

41. Vakili, M. et al. (2014). Application of chitosan and its derivatives as adsorbents for dye removal from water and wastewater: A review. Carbohydr. Polym., 113, 115-130. https://doi.org/10.1016/j.carbpol.2014.07.007 